DOI: $10.20472 /$ IAC.2019.052.037

\author{
PHINDILE MDLULI \\ North-West University, South Africa \\ PRECIOUS MNCAYI \\ North-West University, South Africa \\ THABANG MC CAMEL \\ North-West University, South Africa
}

\title{
EXAMINING FACTORS THAT DRIVE GOVERNMENT SPENDING IN SOUTH AFRICA
}

\begin{abstract}
:
The structure of budgets has changed drastically in the past three decades both globally and locally. Most economies have consistently had growing government spending, some spending way more than what they earn especially following the aftermath of the global financial crisis. Literature shows that government spending in high-income countries has been more on social protection, while public servants compensation has dominated spending in many low-income countries, especially in Africa. In South Africa, a weak investment climate, established years of slow economic progress, rising unemployment and poverty levels which have negatively affected the tax base and therefore revenue collection. The country has been spending more money than it earns, to an enormous degree raising worries to research the drivers of this growth in expenditure, subsequently the essential objective of this study was to pinpoint the key factors that have added to this situation. The study adopted a quantitative research approach through the use of quarterly time series data spanning from 1995 through to 2018. An autoregressive distributed lag (ARDL) model was utilized so as to determine the long-and short-run impacts of the chosen variables on government spending. The findings of the study show that government spending in South Africa, particularly after 1994 has been driven more by current spending than capital spending which presents significant economic effects in the long-run. Among the most significant factors, explicitly in the short run, incorporate unemployment levels, rising debt and inflation. Results further revealed that political instability, low economic growth as well as a growing public size and bailouts of unproductive state owned entities (SOEs) induced significant long term consequences on spending. The continued worsening of spending patterns suggests the presence of fundamental obstacles including the country's high unemployment levels, for both adults and youth, inferring that the revenue base keeps on narrowing, while the growing poverty levels forces spending towards current spending such as the growing social welfare needs rather than productive activities such as investment spending. The study recommends that the size of the public wage bill be reduced and many unproductive SOEs be privatized to relieve spending. Additionally, a multidimensional approach is needed which entails the reduction of debt accumulation to have low interest repayments, restructuring the labour market to improve outcomes, expanding the revenue base, creating an environment conducive to private spending and economic growth and promoting a stable and transparent political climate.
\end{abstract}

\section{Keywords:}

Expenditure, government spending, capital expenditure, current expenditure, South Africa 
JEL Classification: E20, E62, H50 


\section{Introduction}

Government spending is a substantial tool of fiscal policy, its effects on economic growth are still widely debated (Fouladi, 2010; Danladi, Akomolafe \& Olarinde \& Anyadiegwu et al., 2015; Mazorodze, 2018). To provide a conducive and inclusive economy for all the government is expected to carry out certain functions (Oladele, Mah \& Mongale, 2017). Hayek (1944) proposes that one of the significant roles of the government is to function as a safety net. Baro (1990) posit that increased government spending in social and infrastructural aspects stimulates economic development and growth, on the contrary Chipaumire, Ngirande and Method (2014) argue that government spending increases national debt and negatively affects both taxation and inflation and subsequently economic growth. However, in reality there are several factors that act as drivers of government expenditure. Government spending has grown vastly in many countries over the years and has been identified as a prominent role player in developing and developed countries alike, providing public services, revenue supplements and governing the economy, government spending echoes the policy decisions of public servants which affects national output (Uzuner et al., 2017).

The government decides on the magnitude and quality of goods and services to be produced, its spending reflects the expense of executing the planned policies. However, in some countries government spending is a policy worry although there is no general consensus which challenges the growth of government spending (Aregbeyen \& Akpan, 2013), particularly in developing countries where government spending tends to be inherently unstable. Government spending can be defined as money channelled to public services and governing of public affairs. It is money used towards provision of public goods and services in the economy as well as management of state affairs (Danladi et al., 2015). Government spending affects the economic position of individuals and families through two main channels: changes in earnings and changes in gross income. When government alters the level or mix of its expenditures, relative factor income and the relative prices of goods and services produced in the private sector are affected. Government expenditures also affects the well-being of individuals and families through direct cash transfers and the benefits generated by the public provision of goods and services (Shah, 2005).

Literature proposes that government is meant to intervene by providing goods and services that the market system would otherwise underprovide and to correct some market failures (Bourne, Meakin \& Minford, 2016; Stratmann \& Okolski, 2010). According to Oladele et al. (2017) over the years spending by government in South Africa has been rather unstable and unsuccessful in narrowing the inequality gap. In the send quarter of 2019, South Africa's government spending increased to R651189 million from R64667 million (Trading Economics, 2019). Government spending continues to grow at an alarming rate in South Africa, understanding the drivers and determinants is of the country's spending is of utmost importance. The rest of the paper is organised as follows: section 2 discusses the literature, with particular attention to theories of government spending. Section 3 touches on the methodology, followed by results and discussion. The last section concludes the study and provides recommendations thereof. 


\section{Literature Review}

\subsection{Main theories of government spending}

Patterns of public spending affect economic growth in at least two ways. First, broad allocations of spending among government functions may affect overall growth rates because some categories of activities appear to spur growth more than others. Second, within each broad category of spending it is possible to allocate resources more or less efficiently and effectively (The World Bank, 2007). Keynesian economics is of the view that government spending stimulates economic growth and evens out short-run fluctuations in total expenditure (Ju-Huang, 2006). The Keynesian school of thought therefore advocates for an active role of the government in the economy through public spending and money stock in an effort to stimulate aggregate demand and reduce unemployment levels. Idenyi, Ogonna, Chinyere and Chibuzor (2016) concurs, adding that in South Africa's quest to achieve better living standards, the government often centers spending towards the important macroeconomic objectives such as full employment, economic growth, poverty reduction and price stability. On the contrary Classical economics proposes that government intervention is redundant and if spending by government is increased it will not lead to an increase in national output. Therefore, Classical economists' view government spending as a hindrance to economic growth instead of a driver and thus advocates for a free market system (Chipaumire et al., 2014).

Wagner's law proposes that an increase in per capita income leads to an increase in government spending (Wagner, 1977). In other words, as income per capita increases, aggregate demand for goods and services provided by the government also increases, prompting the government to increase its spending (Mthethwa, 1998; Oladele et al., 2017). Therefore, spending by government will tend to increase more than proportionally (Aladejare, 2013). Essentially this is due to evolving technology as a result of industrialisation and urbanization that necessitates growth in income (Mthethwa, 1998). Wagner argues that as a result, the income elasticity of demand for public goods and services will be greater than unity (Alm \& Embaye, 2011). Wijeweera and Garis (2009) opines that in accordance to Wagner's Law government spending accumulates much faster in comparison to national revenue. In practice national income and production should exceed government spending in the long-run. Odhiambo (2015) tested the rationality of Wagner's law in South Africa and contends that government spending is an important source of economic growth. Odhiambo further opines that the increase in spending post-apartheid is the result of increased demand for public services by the previously disadvantaged individuals.

Peacock and Wiseman's theory suggests that there are permanent effects that arise in the society which may lead to increased government spending regardless of social and political attributes. Influences such as economic crises and social upheavals (war, famine etc.) require swift government spending (Peacock \& Wiseman, 1961). To finance these disturbances and shocks in government spending, the government has to increase taxes. This leads to what Peacock and Wiseman refer to as the "displacement effect" where tax payers become immune to paying high taxes during an economic crisis, thus high government spending becomes permanent and does not revert to its original level (Mthethwa, 1998; Alm \& Embaye, 2011). On the other hand, Rostow-Musgrave model proposes that in the initial stages of economic development the 
level of government spending in the economy will be high. The government provides infrastructural facilities such as such as law and order, health care, education, roads, electricity and water. Undertaking these projects entail large capital outlays, thus a rapid increase in government spending. Investment in these social overheads is necessary to drive the economy from traditional to maturity stage of economic development, as a result, over time government spending will increase with the goal of achieving equitable opportunities for all (Aladejare, 2013).

\subsection{Government spending overview in South Africa}

The rapid increase in South Africa's economic growth during the twentieth century improved living standards of the country. However, to sustain an inclusive and growth driven economy the government is expected to act in a distinctive manner (Oladele et al.,2017). The global financial crisis in 2008 and the consequential 2009 slump in economic activity gave birth to a structural budget deficit in South Africa (National Treasury, 2018). The country has since leaned towards a countercyclical fiscal policy, incurring large budget shortfalls while anticipating Gross Domestic Product (GDP) growth in a view to increase tax revenue collection to finance government debt (Worthington, 2019). The government has strived to abolish the deficit indefinitely, but nearly 10 years post the crisis, public finances have not fully recovered. The gap in finances can be attributed to policy decisions, pressure in expenditure and decreasing GDP (National Treasury, 2018).

Government debt is an important fiscal variable thoroughly scrutinised by credit ratings agencies. The international credit rating agencies have been rather uneasy regarding the country's debt, mainly its sustainability (Industrial Development Corporation (Industrial Development Corporation (IDC), 2019). The unstable trail of government debt amplifies South Africa's economic challenges, thus draining off a high percentage of government revenues, slowing down GDP growth and leading to less inclusive growth. From 1992 to 2018, an increase in public debt was experienced from approximately R200 billion to roughly R3 trillion respectively (Mapenzauswa, 2019; IDC, 2019). The main source of this, is the significantly large gap between the country's spending and its revenues. The rapid increase in debt at a rate higher than GDP does not only make the economy vulnerable, but also mirrors weaknesses in the country's finances and its total spending. A substantial amount of national income is consequently consumed by loan payments by the public sector (Mapenzauswa, 2019). Recently, debt-servicing expenses have been growing rapidly compared to other expenditure items and are forecasted to represent 12.6 percent of the total budget expenditure in three years' time (IDC, 2019).

Over the years, there has been instability in the percentage of government expenditure to economic growth in the country. With a ratio of 20 percent in 2006, which subsequently fell to 19 percent between 2007 and 2008, the ratio picked up again to 21 percent during the recessionary period of 2009 (indicating the highest government expenditure between 1960 to 2011) (Odhiambo, 2015). The effects of government spending on GDP are still widely debated, with some arguing that government spending in South Africa has a positive effect on growth, while others argue otherwise (Mthethwa, 1998; Alm \& Embaye, 2011; Oladele et al., 2017; Idenyi, 2016). Nonetheless economic growth has been rather sluggish in the country for a while now. Government's intervention in the market and public finance resulted in the rise of 7 percent (31.4 
percent in 1992 to 1993 from 24.4 percent in 1970-1980) in government spending to GDP. Consequently, the tax burden remains heavier, creating a deficit between current spending and current revenue. Government spending can result in economic sluggishness, similarly, misallocation of finances due to too much money in circulation leads to increased spending (Oladele et al., 2017). However, Mitchelle (2005) argue that high government spending increases costs and eventually leads to government borrowing, which turns to outweigh government revenue and is consequently financed through increased taxes. According to the IDC (2019), economic sluggishness and revenue collection (due to inability to raise taxes) obstacles have a negative effect on government finances, hindering the reduction of government spending.

Government guarantees remain a big challenge to the country's fiscus, poor performance of state owned enterprises continue to rise government spending, for instance, about 69 billion has been channelled towards bailing out Eskom, while R1 billion was accorded to Denel to ease cash flow strains, yet there is still no guarantee that the SOE's will fully recover ((National Treasury, 2019). The rise in economic growth and improvement in living standards is associated with an increase in capital formation in some developing countries (Ncanywa \& Makhenyane, 2016). Capital spending is a common tool used to achieve the functions of the government, although it is rather vulnerable to economic shocks, it does nonetheless serve a prominent purpose in amplifying the forces at work in the growth of government spending (Oladele et al., 2017). Akanbi (2016), argues that investment spending contributes immensely towards unemployment, poverty and inequality eradication. Government has increased spending post-apartheid in order to address the injustices of apartheid. Nonetheless, investment spending has declined over the years (Meyer \& Muzindutsi, 2017). According to Stoddard (2019) and Stats SA (2019), capital formation has been down by 5.2 percent since 2017, Stoddard attributes the lacklustre economic performance to corruption, maladministration and impulsive fiscal policy.

The government has endeavoured to narrow the gap in infrastructure particularly in areas mostly occupied by black South Africans. The persistent increase in unemployment has contributed significantly to the increase in government spending in the capacity of social provision, although government spending has also increased due to employment in the public sector (Bernstein, 2019). The public sector compensation bill makes up a considerable proportion of government spending. Between 2006 and 2018, the wage bill increased to 58.1 percent from 53.7 percent of all current public sector payments (accounting for 35 percent of government spending). Wages and benefits public servants receive over and above their normal compensation drive up government spending, these costs continue to increase at a rate higher than that of employment. The compensation bill has over the years created gaps in social services, in 2018 alone, the wage bill exceeded the projected budget by an astounding amount of R30.2 billion, thus fuelling the shortfall in other departments (Fonkam \& Simkins, 2019).

\subsection{Empirical findings}

Studies have endeavoured to examine the determinants and drivers of government spending in both developed and developing economies. A study conducted by Ukwueze (2015) in Nigeria, in an attempt to determine the size of the public sector in Nigeria, found that revenue and investment spending have an influence on government spending in the short-run. The study 
reports that public debt tends to increase government spending and subsequently hinders growth. In their study, Lamartina and Zaghini (2010) reported that government spending can escalate due to corruption, inefficiencies and rent-seeking behaviour, which further leads to increases in tax, negatively affecting the tax payer. The study further contends that overtime the positive correlation between government spending and economic growth is diminishing and will eventually lead to augmented spending in Nigeria. A study examining public spending and Wagners law attributes increased government spending to economic upswings, the study reported that during an upswing the government tends to spend proportionately more than they do when the economy is experiencing a downswing (Akitoby et al., 2006). An econometric panel study by Fölster and Henrekson (2001) reported an inverse relationship between government spending and economic growth in developed countries (such as Chile, Hong Kong, Singapore). Implying that an increase in government spending is accompanied by a decrease in economic growth (GDP). Chipaumire et al. (2014) reports similar results and attributes the negative relationship between government spending and economic growth to inadequacies in government plans, leading to improvidence and wastefulness of scarce economic resources. In a study analysing the correlation between the size of the government and the unemployment rate, using computable general equilibrium models, Burton (1999) reports a significant relationship between rises in unemployment and government spending. Fouladi (2010), finds that an increase in government spending reduces investment, production and employment, the study further reports that spending in investment will yield different results depending on where and what is being invested on.

\section{Methodology}

\subsection{Data and variable description}

The aim of the study is to examine key factors that drive government spending in post-apartheid South Africa. The study utilises secondary data from 1995Q1 - 2018Q4 which totals to 92 quarterly observations. As a result, a quantitative research design, following a functionalist approach (Lazarsfeld, 1951) is thought to be an appropriate design choice. The statistical tool used is the Econometric Views (E-Views) version 11. It should be noted that all the data used in the study were transformed into natural logarithmic (L) to ensure stationarity in the variable and to obtain elasticities (i.e. percentage changes). Variables used in the study (see Table 1 below) were all sourced from the South African Reserve Bank and seasonally adjusted. A dummy variable was created for the Global Financial Crisis (GFC) to capture the impact the crisis may have had on government spending.

Table 1: Chosen Variables

\begin{tabular}{|l|l|}
\hline Variable code (Proxy) & Variable description \\
\hline LGOVSP & Government spending (explanatory variable) \\
\hline & \multicolumn{2}{|c|}{ Explained variables } \\
\hline LGDP & Gross domestic product \\
\hline LGOVREV & Government revenue \\
\hline LGFCF & Gross fixed capital formation by government \\
\hline LGOVGUA & $\begin{array}{l}\text { Government guaranteed debt to capture the } \\
\text { debt the government has assumed on SOEs }\end{array}$ \\
\hline
\end{tabular}




\begin{tabular}{|l|l|}
\hline LDEBT & Total government debt \\
\hline LGOVCO & Government compensation of employees \\
\hline LEMP & $\begin{array}{l}\text { Non-agricultural employment to capture the } \\
\text { social aspect }\end{array}$ \\
\hline
\end{tabular}

\subsection{Model specification}

The study utilised the autoregressive distributed lag (ARDL) model to capture the impact of the chosen explanatory variables on government spending in South Africa. The choice of this estimation model is purely based on its ability to produce results that are consistent (Arodoye \& lyoba, 2014) relative to other models such as ordinary least squares (Mina, 2011). Additionally, the model permits the use of the data irrespective of whether it is stationary at $\mathrm{I}(0), \mathrm{I}(1)$ or a combination (Pesaran \& Shi, 1999). The following equation is estimated:

$$
\begin{aligned}
\Delta L G O V S P_{\mathrm{t}}=\alpha_{0}+ & \sum_{\mathrm{i}=1}^{n} \beta_{1 \mathrm{i}} \Delta L G D P_{\mathrm{t}-\mathrm{i}}+\sum_{\mathrm{i}=1}^{n} \beta_{2 \mathrm{i}} \Delta L G O V R E V_{\mathrm{t}-\mathrm{i}}+\sum_{\mathrm{i}=1}^{n} \beta_{3 \mathrm{i}} \Delta L G F C F_{\mathrm{t}-\mathrm{i}}+\sum_{\mathrm{i}=1}^{n} \beta_{4 \mathrm{i}} \Delta L G O V G U A_{\mathrm{t}-\mathrm{i}} \sum_{\mathrm{i}=1}^{n} \beta_{5 i} \Delta L D E B T_{\mathrm{t}-\mathrm{i}} \\
& +\sum_{\mathrm{i}=1}^{n} \beta_{6 \mathrm{i}} \Delta L G O V C O_{\mathrm{t}-\mathrm{i}}+\sum_{\mathrm{i}=1}^{n} \beta_{7 i} \Delta L E M P_{\mathrm{t}-\mathrm{i}}+\phi_{1} L G D P_{\mathrm{t}-1}+\phi_{2} \text { LGOVREV }_{\mathrm{t}-1}+\phi_{\mathrm{a}} L G F C F_{\mathrm{t}-1}+\phi_{4} L G O V G U A_{\mathrm{t}-1} \\
& +\phi_{5} L D E B T_{\mathrm{t}-1}+\phi_{\mathrm{s}} L \text { GOVCO }_{\mathrm{t}-1}+\phi_{7} L E M P_{\mathrm{t}-1}+\varepsilon t
\end{aligned}
$$

Where $\triangle$ LGOVSP denotes spending by government at time (t), followed by $\triangle$ LGDP which signifies gross domestic product at time (t), $\triangle$ LGOVREV which symbolises government revenue at time (t), $\triangle \mathrm{LGFCF}$ indicates investment spending by government at time (t), $\triangle$ LGOVGUA indicates government guaranteed debt at a time (t), $\Delta$ LDEBT at a time (t) represents total government debt and $\triangle \mathrm{LGOVCO}$ represents government compensation at time (t), while $\Delta \mathrm{LEMP}$ denotes non-agricultural employment rate at a time (t). Both $\alpha 0$ and $n$ signify the intercept as well as the number of lags used. The short-run dynamics are symbolised by $\beta 1$ to $\beta 7$, while the longrun relationship and the error term are both represented by $\phi 1$ to $\phi 7$ and $\varepsilon t$ respectively.

Firstly, to ensure that the data is stationary and viable study results, the unit root test (augmented Dickey-Fuller (ADF) is undertaken. The ADF test is often used to determine the unit roots and order of integration in time series data. The test hypothesis is presented below:
$\boldsymbol{H}_{\mathbf{0}}$ : Unit root in the series (not stationary)
$H_{1}$ : No unit root in the series (stationary)

Secondly, to assess whether the explanatory variables have a long-run impact on the explained variable, an ARDL is used to test for cointegration. The following hypothesis testing for cointegration is proposed:

\section{$\boldsymbol{H}_{0}$ : No cointegration (no long-run relationship) \\ $H_{1}$ : Cointegration (long-run relationship)}

The two hypothesis are tested using the bounds test through the Wald f-test (Pesaran, Shin \& Smith, 2001). The $H_{0}$ of no long-run relationship is rejected if the F-statistic is greater than both the critical values of the lower bound and the upper (Mc Camel, 2018). This will suggest the existence of a long-run relationship between the explained and explanatory variables of the study. The opposite is true when the F-statistic is less than the critical values, the $H_{0}$ cannot be rejected which would mean that a long-run relationship between the variables does not exist (Mothibi \& 
Mncayi, 2019). In the case where there is cointegration between the variables, then the error correction model (ECM) will be estimated as a third step and it will be in the following way:

$$
\begin{aligned}
\Delta L G O V S P_{\mathrm{t}}=a_{0}+ & \sum_{\mathrm{i}=1}^{n} \beta_{1 \mathrm{i}} \Delta L G D P_{\mathrm{t}-\mathrm{i}}+\sum_{\mathrm{i}=1}^{n} \beta_{2 \mathrm{i}} \Delta L G O V R E V_{\mathrm{t}-\mathrm{i}}+\sum_{\mathrm{i}=1}^{n} \beta_{3 \mathrm{i}} \Delta L G F C F_{\mathrm{t}-\mathrm{i}}+\sum_{\mathrm{i}=1}^{n} \beta_{4 \mathrm{i}} \Delta L G O V G U A_{\mathrm{t}-\mathrm{i}} \sum_{\mathrm{i}=1}^{n} \beta_{5 \mathrm{i}} \Delta L D E B T_{\mathrm{t}-\mathrm{i}} \\
& +\sum_{\mathrm{i}=1}^{n} \beta_{6 \mathrm{i}} \Delta L G O V C 0_{\mathrm{t}-\mathrm{i}}+\sum_{\mathrm{i}=1}^{n} \beta_{7 \mathrm{i}} \Delta L E M P_{\mathrm{t}-\mathrm{i}}+\delta E C T_{\mathrm{t}-1}+\varepsilon t
\end{aligned}
$$

In equation 2, ECT and $\delta$ denotes the error correction term and its coefficient respectively. According to Masih and Masih (1997) the ECM presents the error correction term (ECT) which measures the speed of adjustment towards long-run equilibrium. In selecting the optimal number of lags, the Akaike Information Criterion was utilised. As the last step, to test for the chosen model's reliability and accuracy, residual diagnostic tests (i.e. normality, heteroscedasticity and serial correlation tests) will be done to ensure model stability. The results and discussions are presented in the next section.

\section{Results and discussions}

\subsection{Correlation analysis}

In determining the strength and relationship between the chosen variables, the Pearson correlation analysis was conducted, the correlation coefficient value must range between -1 and +1 . As indicated by Gogtay and Thatte (2017) the closer the correlation coefficient is to +1 , the stronger the association between two variables, while correlation coefficient of -1 signifies a perfectly negative linear relationship. A zero correlation coefficient point to no linear relationship between the two variables under study. The results of the correlation analysis are presented in Table 1. From the table, it can be seen that a weak to medium positive relationship exists between gross fixed capital formation by government (LGFCF), LDGP and government spending (GOVSP). These results were statistically significant at the 0.5 level of significance. In addition, a weak to strong positive association is observed between government spending and LGOVCO, LEMP and government guaranteed debt (LGOVGUA). The correlation between government spending and LGOVREV and LDEBT positive but weak. All associations between the explanatory and explained variables were all statistically significant at the 0.5 significance level.

\begin{tabular}{|c|c|c|c|c|c|c|c|c|}
\hline Probability & LGOVSP & LGOVCOM & LGFCF & LGDP & LEMP & LDEBT & LGOVREV & LGOVGU \\
\hline \multirow[t]{2}{*}{ LGOVSP } & 1.000000 & & & & & & & \\
\hline & ----- & & & & & & & \\
\hline \multirow[t]{2}{*}{ LGOVCOM } & 0.546030 & 1.000000 & & & & & & \\
\hline & $0.0000^{*}$ & ----- & & & & & & \\
\hline \multirow[t]{2}{*}{ LGFCF } & 0.492508 & 0.953032 & 1.000000 & & & & & \\
\hline & $0.0000^{*}$ & $0.0000^{*}$ & ----- & & & & & \\
\hline \multirow[t]{2}{*}{ LGDP } & 0.489464 & 0.984057 & 0.972868 & 1.000000 & & & & \\
\hline & $0.0000^{*}$ & $0.0000^{\star}$ & $0.0000^{*}$ & ----- & & & & \\
\hline LEMP & 0.596050 & 0.906059 & 0.936589 & 0.918351 & 1.000000 & & & \\
\hline
\end{tabular}

Table 1: Pearson correlation results 


\begin{tabular}{|c|c|c|c|c|c|c|c|c|}
\hline & $0.0000^{*}$ & $0.0000^{*}$ & $0.0000^{*}$ & 0.0000 * & ----- & & & \\
\hline \multirow[t]{2}{*}{ LDEBT } & 0.330548 & 0.055361 & -0.121151 & -0.099304 & 0.002646 & 1.000000 & & \\
\hline & $0.0010^{*}$ & 0.5921 & 0.2397 & 0.3357 & 0.9796 & ----- & & \\
\hline \multirow[t]{2}{*}{ LGOVREV } & 0.310544 & 0.430490 & 0.476367 & 0.449023 & 0.470141 & -0.061438 & 1.000000 & \\
\hline & $0.0021^{*}$ & $0.0000^{*}$ & $0.0000^{*}$ & $0.0000^{*}$ & $0.0000^{*}$ & 0.5521 & ----- & \\
\hline \multirow[t]{2}{*}{ LGOVGUA } & 0.597230 & 0.859724 & 0.731798 & 0.772073 & 0.742696 & 0.537455 & 0.333946 & 1.000000 \\
\hline & $0.0000^{*}$ & $0.0000^{*}$ & $0.0000^{*}$ & $0.0000^{*}$ & $0.0000^{*}$ & $0.0000^{*}$ & $0.0009^{*}$ & ----- \\
\hline
\end{tabular}

\section{Note: $\left(^{*}\right)$ indicates $5 \%$ Significant level}

Source: Compiled by the authors (Data from SARB, 1995Q1-2018Q4)

\subsection{Unit root testing}

In testing for the order of integration of the variables, namely stationarity, the study utilised the ADF unit root test. The unit root test results given in Table 2 show that some of the variables used in the study are stationary at level, while others are stationary at first difference. Specifically, the natural log of non-agricultural employment (LEMP), natural log of GDP (LGDP), natural log of gross fixed capital formation by government (LGFCF), natural log of government employee compensation (LGOVCOM), natural log of government spending (LGOVSP), natural log of government debt guarantee (LGOVGUA) and natural log of government revenue (LGOVREV) were all stationary at I(1) without trend after being first differenced. While LDEBT was stationary at I(1) without trend and intercept.

Table 2: Unit root results (ADF)

\begin{tabular}{|c|c|c|c|c|c|c|c|c|c|c|c|}
\hline \multirow[t]{3}{*}{ Variable } & \multicolumn{4}{|c|}{ Levels } & \multicolumn{6}{|c|}{$1^{\text {st }}$ Difference } & \multirow{3}{*}{$\begin{array}{c}\text { Order } \\
\text { of } \\
\text { integra } \\
\text { tion }\end{array}$} \\
\hline & \multicolumn{2}{|c|}{ Without trend } & \multicolumn{2}{|c|}{ With trend } & \multicolumn{2}{|c|}{ Without trend } & \multicolumn{2}{|c|}{ With trend } & \multicolumn{2}{|c|}{ None } & \\
\hline & t-stats & P-val. & t-stats & P-val. & t-stats & P-val. & t-stats & P-val. & t-stats & P-val. & \\
\hline LDEBT & -1.498 & 0.530 & -1.374 & 0.862 & -2.004 & 0.285 & 2.8095 & 0.198 & -1.998 & $0.044^{*}$ & $\mathrm{I}(1)$ \\
\hline LEMP & -0.757 & 0.826 & -2.114 & 0.531 & -4.454 & $0.001^{*}$ & --------- & ------- & -------- & ------- & $\mathrm{I}(1)$ \\
\hline LGDP & -1.635 & 0.461 & -0.364 & 0.988 & -12.928 & $0.000^{*}$ & --------- & ------- & -------- & ------- & $\mathrm{I}(1)$ \\
\hline LGFCF & -1.079 & 0.721 & -2.268 & 0.447 & -7.454 & $0.000^{*}$ & --------- & ------- & -------- & -------- & $\mathrm{I}(1)$ \\
\hline $\begin{array}{l}\text { LGOVCO } \\
\text { M }\end{array}$ & -0.419 & 0.901 & -1.922 & 0.635 & -3.283 & $0.019^{*}$ & --------- & ------- & ------- & -------- & $\mathrm{I}(1)$ \\
\hline LGOVSP & -0.696 & 0.842 & -1.4197 & 0.849 & -4.257 & $0.001^{*}$ & --------- & ------- & --------- & -------- & $\mathrm{I}(1)$ \\
\hline $\begin{array}{l}\text { LGOVGU } \\
\text { A }\end{array}$ & 0.222 & 0.973 & -1.381 & 0.861 & -5.751 & $0.000^{*}$ & -------- & $\begin{array}{c}------ \\
-\end{array}$ & --------- & -------- & $\mathrm{I}(1)$ \\
\hline LGOVREV & -1.614 & 0.472 & -3.388 & 0.059 & -6.298 & $0.000^{*}$ & -------- & ------- & --------- & ------- & $\mathrm{I}(1)$ \\
\hline
\end{tabular}

Note: $\left(^{*}\right)$ indicates $5 \%$ Significant level

Source: Compiled by the authors (Data from SARB, 1995Q1-2018Q4) 


\subsection{Model selection}

In selecting the optimal number of lags to include in each of the previously mentioned ARDL model, the study made use of the Akaike Information Criterion (AIC). As such the AIC selected 8 lags as the maximum number of lags to include in the ARDL model that was selected, Therefore the chosen model is the ARDL $(8,0,1,0,0,1,0,0,0)$. Table 3 below comprehensively details the optimal ARDL model selected to estimate Equation 1 and Equation 2.

Table 3: Optimal ARDL models selected

\begin{tabular}{|c|c|c|c|c|c|c|}
\hline \multirow{2}{*}{$\begin{array}{c}\text { Selected } \\
\text { ARDL } \\
\text { model }\end{array}$} & $\begin{array}{c}\text { Lag-length } \\
\text { criterion }\end{array}$ & $\begin{array}{c}\text { Trend } \\
\text { specification }\end{array}$ & $\begin{array}{c}\text { Max. no. } \\
\text { of lags }\end{array}$ & Optimal model & $\begin{array}{c}\text { Adj. R- } \\
\text { square }\end{array}$ & $\begin{array}{c}\text { Prob. } \\
\text { (F-statistic) }\end{array}$ \\
\cline { 2 - 7 } & (AIC) & $\begin{array}{c}\text { Constant } \\
\text { level }\end{array}$ & 8 & $(8,0,1,0,0,1,0,0,0)$ & 0.920333 & 0.000000 \\
\hline
\end{tabular}

Table 3 further shows the adjusted R-square value for the chosen ARDL model which implies that 92 percent of the variation in government spending (GOVSP) can be explained by independent variables under study. While, the $p$-value for the F-statistic is significant, implying that the ARDL model as whole is significant. The next subsection presents the results that were obtained through the estimation of the bound tests and the resultant ECMs for the optimal ARDL model.

\subsection{ARDL Bounds tests and long-run analysis}

Following the unit root testing and the selection of the optimal model, the subsequent step was to determine the existence of cointegration, i.e. long-run relationship between the variables in question. This was done through the utilisation of the ARDL bounds test and the results are summarised in Table 4.

Table 4: Long-run results

\begin{tabular}{|c|c|c|}
\hline \multirow{2}{*}{$\begin{array}{c}|c| \\
\text { ARDL model } \\
(\mathbf{8}, \mathbf{0}, \mathbf{1}, \mathbf{0}, \mathbf{0}, \mathbf{1}, \mathbf{0 , 0 , 0 )}\end{array}$} & \multicolumn{2}{|c|}{ Estimated F-value } \\
\cline { 2 - 3 } & \multicolumn{2}{|c|}{$3.94^{*}$} \\
\hline Critical Value Bounds (Sig.) & Lower bound I(0) & 3.06 \\
\hline $10 \%$ & 1.95 & 3.39 \\
\hline $5 \%$ & 2.22 & 4.1 \\
\hline $1 \%$ & 2.79 & \\
\hline
\end{tabular}

Note: Bound test critical values from Pesaran et al. (2001) Table Cl(V)

Note: $\left(^{*}\right)$ indicates $5 \%$ significance level $r$

Source: Compiled by the authors (Data from SARB, 1995Q1-2018Q4)

The chosen level of significance was at $5 \%$, therefore as can be seen in Table 4, the estimated Fvalue for the selected optimal ARDL model is 3.94 which is greater than the corresponding critical value bounds. This confirms the rejection of the null hypothesis of no long-run relationship. For 
this reason, it can be deduced that there is a long-run relationship between government spending in South Africa and the selected explanatory variables. Equation 3 below summarises the nature of the long-run relationship between the selected explanatory variables and government spending.

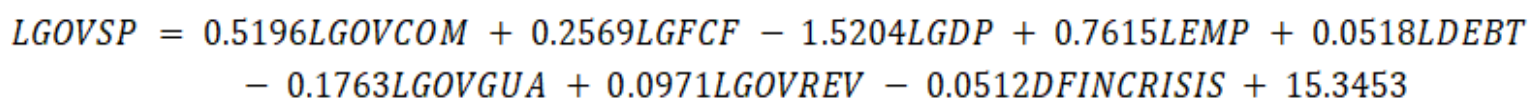

From equation 3 , it seems government spending was positively related to government's compensation of employees, where a one percentage change the government wage bill will result in a 0.52 percentage increase in government spending. These findings suggests that a growing public sector wage bill fuells government spending which mirrors findings of Fonkam and Simkins (2019). Another positive significant association is observed between gross capital formation by government and government spending, which means that a one percent increase in investment spending by government will on average lead to a 0.26 percent increase in government spending. These findings infers that the more the government spends on gross fixed capital formation (investment), the more its overall spending is likely to grow in the long-run.

Government spending is also positively related with employment, total govenrment debt and government revenue, implying that a percentage change in each of these explanatory variables will lead to a 0.76 percent, 0.05 percent and 0.098 percent in government spending respectively. Specifically, in terms of the positive relationship between government revenue and government spending, findings of this study resonates with the underlying assumptions of Wagner's Law (Wagner, 1893) and findings of Ukwueze (2015), which maintains that as government revenue increases, there is a desire by the government to increase spending to meet the demands of the people, which eventually exacerbates government spending. The positive association between employment and employment can be explained by the fact that in most cases, unemployment paves a way for government job creation which is done through fiscal expansions such as government spending (Boushey \& Ettlinger, 2011). Therefore, employment rises because spending has risen. The last positive significant association between government spending and total government debt and these findings are consistent with those of Mothibi and Mncayi (2019) and Mah et al. (2013). The reality is that the pervasiveness of socio-economic challenges confronting South Africa has increased spending on social security as a reduction strategy which has continued to put considerable strain on government debt given how strained government revenues have been owing to high unemployment levels and a declining economy

On the other hand, GDP, government guaranteed debt and the global financial crisis all seem to be negatively associated with government spending in South Africa. These findings lean towards implying that increases in GDP put forth somewhat substantial reduction of 1.5 percent in government spending, confirming the countercyclical nature of fiscal policy in South Africa in the long-run which is line with theory recommendations that suggest government spending as an automatic stabilizer (spending more in bad times, spending less in good times) (Serven, 1998). Szarowská (2011) confirms these findings in the Czech Republic and Worthington (2019). In addition, a one percent change in government guaranteed debt will on average result in a 0.18 percentage decrease in government spending. This implies that government guaranteed debt is 
not a driver of government spending in South Africa. The association between government spending and the financial crisis where the global financial crisis on average reduced government spending in South Africa by 0.05 percent indeed supports the findings on the countercyclical relationship between GDP and government spending (National Treasury, 2018).

\subsection{Short-run analysis and the error correction model (ECM)}

The next stage of the analysis encompassed the estimation of the short-run dynamics between the study variables. Specifically, the ECM provides information on the speed of adjustment back to long-run equilibrium as a result of variations in the observed variables. The results of the error correction model are summaries in Table 5.

Table 5: Short-run results

\begin{tabular}{|c|c|c|c|c|}
\hline \multicolumn{5}{|c|}{ Cointegrating Form } \\
\hline Variable & Coefficient & Std. Error & t-Statistic & Prob. \\
\hline $\mathrm{D}($ LGOVSP $(-1))$ & -0.766081 & 0.181861 & -4.212457 & $0.0001^{*}$ \\
\hline $\mathrm{D}($ LGOVSP $(-2))$ & -0.534521 & 0.177480 & -3.011717 & $0.0036^{*}$ \\
\hline $\mathrm{D}($ LGOVSP $(-3))$ & -0.559355 & 0.172613 & -3.240525 & $0.0018^{*}$ \\
\hline $\mathrm{D}($ LGOVESP $(-4))$ & -0.033407 & 0.166551 & -0.200580 & 0.8416 \\
\hline $\mathrm{D}($ LGOVESP $(-5))$ & -0.072729 & 0.148197 & -0.490760 & 0.6252 \\
\hline $\mathrm{D}($ LGOVESP $(-6))$ & -0.287983 & 0.128150 & -2.247234 & $0.0278^{*}$ \\
\hline $\mathrm{D}($ LGOVESP $(-7))$ & -0.305558 & 0.092495 & -3.303515 & $0.0015^{*}$ \\
\hline $\mathrm{D}($ LGOVCOMP) & 0.190352 & 0.093301 & 2.040181 & $0.0452^{*}$ \\
\hline $\mathrm{D}$ (LGFCF) & -0.045941 & 0.106465 & -0.431512 & 0.6674 \\
\hline $\mathrm{D}($ LGDP) & -0.556968 & 0.304626 & -1.828369 & 0.0718 \\
\hline $\mathrm{D}($ LEMP) & 0.278950 & 0.362313 & 0.769914 & 0.4440 \\
\hline $\mathrm{D}($ LDEBT $)$ & 0.635433 & 0.221199 & 2.872676 & $0.0054^{*}$ \\
\hline D(LGOVGUAR) & -0.064580 & 0.049766 & -1.297670 & 0.1987 \\
\hline D(LGOVREV) & 0.035575 & 0.048979 & 0.726329 & 0.4701 \\
\hline D(DFINCRISIS) & -0.018751 & 0.019160 & -0.978680 & 0.3312 \\
\hline CointEq(-1) & -0.366320 & 0.182950 & -2.002294 & $0.0492^{*}$ \\
\hline
\end{tabular}

\section{Note: $\left(^{*}\right)$ indicates $5 \%$ significance level}

Source: Compiled by the authors (Data from SARB, 1995Q1-2018Q4)

The ECT CointEq(-1) is negative and significant at the $5 \%$ level of significance with a coefficient of -0.366320 and a probability value of 0.0492 , which mean that 36.63 percent of any disequilibrium between government spending and the chosen independent variables is reestablished back to equilibrium at each quarter interim. Put differently, it takes approximately 2.729 (1/0.366320) quarters to restore equilibrium in government spending the selected explanatory variables change. In the short-run, Table 5 shows that the short-run coefficient for government spending is positive, implying that previous changes in government spending have a positive impact on the present-day government spending. In addition, government spending is stimulated in the short-run by the compensation of its own employees and its own total debt. Government gross capital formation, GDP, employment levels, government guaranteed debt, government revenue and the global financial crisis are statistically not significant, and therefore have no short-run effect on government spending. 


\subsection{Diagnostic and stability tests}

The results of the residual diagnostic and stability tests are reported in Table 6 below. The importance of performing these tests ensures the reader of the appropriateness of the chosen model as well as false and misleading results (Mc Camel, 2018). From the table, it can be confirmed that all residuals were normally distributed and the selected variables were homoscedastic without the presence of serial correlation present.

Table 6: Residual diagnostics

\begin{tabular}{|l|l|c|}
\hline \multirow{2}{*}{ Residual diagnostic test } & \multicolumn{2}{|c|}{ ARDL model $(\mathbf{8 , 0 , 1 , 0 , 0 , 1 , 0 , 0 , 0 )}$} \\
\cline { 2 - 3 } & P-value & Decision \\
\hline Normality Test (JB) & $0.1556^{*}$ & Do not reject $\mathrm{H}_{0}$ \\
\hline Serial-correlation: Breusch-Godfrey (LM test) & $0.4405^{*}$ & Do not reject $\mathrm{H}_{0}$ \\
\hline Heteroskedasticity Test: Breusch-Pagan-Godfrey & $0.4798^{*}$ & Do not reject $\mathrm{H}_{0}$ \\
\hline
\end{tabular}

Note: $\left(^{*}\right)$ Non-rejection of the null hypothesis at $1 \% ; 5 \%$ \& $10 \%$ significance levels

Note: $\left({ }^{*}\right)$ indicates $5 \%$ Significant level

Source: Compiled by the authors (Data from SARB, 1995Q1-2018Q4)

\section{Conclusions and Recommendations}

The aim of this study was to examine factors that drive government spending in South Africa. The ARDL model found a positive relationship between government spending and the compensation of its employees. This shows that a growing public sector wage bill is detrimental to fiscal sustainability since government revenue has been under tremendous pressure exacerbated by an increasing number of people without employment and a stagnating economy that has not been growing at all. There is therefore a need to reduce the government wage bill where the current implementation measures on encouraged early retirement options can be enhanced even more. Hiring more young people will cost less and therefore greatly assist towards lowering youth unemployment. A positive relationship was also determined between government spending and government debt. A growing government debt consumes substantial amounts from government revenues and depending on where the debt is used (i.e. to finance current or capital spending), it could slow down GDP, hence it is imperative to bridge the gap between government spending and government revenues. Furthermore, strict regulations must be implemented for state owned entities, particularly highly indebted ones like Eskom and dependence on government eliminated. SOE bailouts must be granted through a specified criterion, better yet, state monopolies be allowed to compete with the private sector. 


\section{References}

Alm, J. \& Embaye, A. 2011. Explaining the growth of government spending in South Africa. Tulane Economics Working Paper Series, Working Paper 1105, New Orleans.

Akanbi, O. 2016. The growth, poverty and inequality nexus in South Africa: Cointegration and causality analysis. Development Southern Africa, 33(1):1-20.

Akitoby, B., Clements, B., Gupta, S. \& Inchauste, G. 2006. Public spending, voracity, and Wagner's law in developing countries. European Journal of Political Economy, 22:908-924.

Aladejare, S.A. 2013. Government spending and economic growth: evidence from Nigeria. Federal University Wukari, Nigeria.

Alm, J. \& Embaye, A. 2011. Explaining the growth of government spending in South Africa. Tulane Economics Working Paper Series, Working Paper 1105, New Orleans.

Aregbeyen, O.O. \& Akpan, U.F. 2013. Long-term Determinants of Government Expenditure: A Disaggregated Analysis for Nigeria. Journal of Studies in Social Sciences, 5(1): 31-87.

Arodoye, N.L. \& lyoha, M.A. 2014. Foreign trade-economic growth nexus: evidence from Nigeria. CBN. Journal of Applied Statistics, 5(1):121-138.

Baro, R. 1990. Government spending in a Simple Model of Endogenous Growth. Journal of Political Economy, 98(5):103-125.

Bernstein, A. 2019. Heading off disaster. https://www.politicsweb.co.za/opinion/heading-offdisaster. Date of access: 17/09/2019.

Bourne, R., Meakin, R., Minford, L., Minford, P. \& Smith, D.B. 2016. Taxation, Government Spending and Economic Growth. The Institute of Economic Affairs, London.

Boushey, ,H. \& Ettlinger, M. 2011. Government Spending Can Create Jobs-and It Has. Centre for American Progress.

https://www.americanprogress.org/issues/economy/reports/2011/09/08/10257/governmentspending-can-create-jobs-and-it-has/ Date of access: 15/09/2019.

Burton, A. 1999. The Effect of Government Size on the Unemployment Rate. Public Choice, 99:3-4.

Chipaumire, G., Ngirande, H., Method, M. \& Ruswa, Y. 2014. The Impact of Government Spending on Economic Growth: Case South Africa. Mediterranean Journal of Social Sciences, 5(1):109-118.

Danlad, J.D., Akomolaf, K.J., Olarinde, O.S. \& Anyadiegwu, N.L. 2015. Government Expenditure and Its Implication for Economic Growth: Evidence from Nigeria. Journal of Economics and Sustainable Development, 6(18):142-150.

Fölster, S. \& Henrekson, M. 2001. Growth effects of government expenditure and taxation in rich countries. European Economic Review, 45(8):1501-1520.

Fonkam, A. \& Simkins, C. 2019. Budget challenges III: Revenue and expenditure. https://www.politicsweb.co.za/opinion/budget-challenges-iii-revenue-and-expenditure Date of access: 16/09/2019. 
Fouladi, M. 2010. The Impact of Government Expenditure on GDP, Employment and Private Investment a CGE Model Approach. Iranian Economic Review, 15(27):54-75.

Gogtay, N.J. \& Thatte, U.M. Principles of correlation analysis. Journal of the Association of Physicians of India, 65:78-81.

IDC (Industrial Development Corporation). 2019. National Budget 2019: Aiming for stability to create a sound platform for renewal. https://www.idc.co.za/wpcontent/uploads/2019/02/National-Budget-2019-Review-by-IDC-Research-Information-andLegal-Services-departments-21-February-2019-External-release.pdf Date of access: 16/09/2019.

Idenyi, O.S., Ogonna, I.C., Chinyere, U.C. \& Chibuzor, C.B. 2016. Public Expenditure and Economic Growth in South Africa: Long Run and Causality Approach. Asian Journal of Economics, Business and Accounting, 1(2): 1-17.

Ju-Huang, C. 2006. Government expenditures in China and Taiwan: Do they follow Wagner's law? Journal of economic development, 31(2):139-148.

Lamartina, S. \& Zaghini, A. 2010. Increasing Public Expenditure: Wagner's Law in OECD Countries. German Economic Review, 12(2): 149-164.

Lazarsfeld, P.F. 1951. Continuities in social re- search. Glencoe, Illinois: Free Press.

Mah, J; Petersen, J. M; Miruka, C \& Peterson, M. A. (2013). The impact of government expenditure on the Greek government debt: An econometric analysis. Mediterranean Journal of Social Sciences, 4(3):2039-2117.

Mapenzauswa, S. 2019. Budget2019: SA budget deficit to widen as it borrows R1.2bn a day (Full Speech). https://www.iol.co.za/business-report/budget/budget2019-sa-budget-deficit-towiden-as-it-borrows-r12bn-a-day-full-speech-19404658 Date of access: 18/09/2019.

Masih, A.M.M. \& Masih, R. 1997. Temporal causal relationship between energy consumption, real income and prices: Some new evidence from Asian-energy dependent NIC's based on a multivariate cointegration/vector error correction approach. Journal of Policy Modelling, 19(4):417-40.

Mazorodze, B. 2018. Government expenditure and economic growth in Zimbabwe. African Journal of Business and Economic Research, 13(2): 183 - 202.

Mc Camel, R.T. 2018. The impact of manufacturing and its sub-sectors on GDP and employment in South Africa: A time-series analysis. Vanderbijlpark: North-West University. (Dissertation - Mcom).

Meyer, D. \& Muzindutsi, P. The impact of government expenditure and sectoral investment on economic growth in South Africa. Journal of Advanced Research in Law and Economics, 6(28): 1843-1855.

Mina, B. 2011. Growth by destination (where you export matters): trade with China and growth in African countries. African Development Review, 23(2):202-218.

Mitchell, D.J. 2005. The Impact of Government Spending on Economic Growth. The Heritage Foundation. Washington DC. 
Mothibi, L. \& Mncayi, P. 2019. Investigating the key drivers of government debt in South Africa: A post-apartheid analysis. International Journal of eBusiness and eGovernment studies, 11(1):16-33.

Mthethwa, N.R. 1998. Government expenditure growth in South Africa, 1960 - 1993. MComUniversity of Natal.

National Treasury. 2018. Budget Review 2018. Pretoria.

National Treasury. 2019. Budget Review 2019. Pretoria.

Ncanywa, T. \& Makhenyane, L. 2016. Can Investment Activities in the Form of Capital Formation Influence Economic Growth in South Africa?. SAAPAM Limpopo Chapter 5th 270 Annual Conference Proceedings 2016. Limpopo.

Odhiambo, N.M. 2015. Government Expenditure and Economic Growth in South Africa: An Empirical investigation. Atlantic Economic Journal Volume, 43(3): 393-406.

Oladele, M.F., Mah, G. \& Mongale, T. 2017. The role of government spending on economic growth in a developing country. Risk governance \& control: financial markets \& institutions, 7(1): 140-146.

Peacock, A.T. \& Wiseman, J. 1961. The Growth of Public Spending in the United Kingdom. Princeton, NJ: Princeton University Press.

Pesaran, M.H. \& Shin, Y. 1999. An autoregressive distributed-lag modelling approach to cointegration analysis. Econometric Society Monographs, (31):371-413.

Pesaran, M.H.; Shin, Y. \& Smith, R.J. (2001). Bounds testing approaches to the analysis of level relationships. Journal of Applied Econometrics, 16(3), pp. 289326.

Serven, L., 1998: Macroeconomic Uncertainty and Private Investment in LDCs: An Empirical Investigation. World Bank Working Paper No. 2035

Shah, A. 2015. Public sector governance and accountability series: Public Expenditure Analysis. The World Bank Washington, D.C.

Stoddard, E. 2019. Data underlines the woeful state of South Africa's investment climate. https://www.dailymaverick.co.za/article/2019-06-10-data-underlines-the-woeful-state-ofsouth-africas-investment-climate/. Date of access: 17/09/2019.

Stratmann, T. \& Okolski, G. 2010. Civic Participation and Government Spending. Working Paper No. 10-24, George Mason University.

Szarowská, I. Relationship between government spending and economic growth in the Czech Republic. Acta Universitatis Agriculturae Et Silviculturae Mendelianae Brunensis, 44(1):415422.

The World Bank. 2007. Fiscal Policy and Economic Growth: Lessons for Eastern Europe and Central Asia. Washington, DC.

Trading Economics. 2019. South Africa Government Spending. https://tradingeconomics.com/south-africa/government-spending Date of access: 18/09/2019. 
Ukwueze, E.R. 2015. Determinants of the Size of Public Expenditure in Nigeria. University of Nigeria: Nigeria.

Uzuner, G., Bekun, F.V. \& Seyi, S.A. 2017. Public Expenditures and Economic Growth: Was Wagner Right? Evidence from Turkey. Academic Journal of Economic Studies, 3(2):36:40.

Wagner, A. (1893). Grundlegung der Politschen Okonomie [Groundwork of political economy]. Liepzig, Germany: C.F. Winter.

Wagner, R.E. \& W.E. Weber. 1977. Wagner's Law, Fiscal Institutions, and Growth of Government. National Tax Journal, 30.

Wijeweera, A. \& Garis, T. 2009. Wagner's law and social welfare: the case of the kingdom of Saudi Arabia. Applied Econometrics and International Development, 9(2): 199-209.

Worthington, P. 2019. Budget2019: Growth the best solution to SA's fiscal challenges. https://www.iol.co.za/business-report/opinion/budget2019-growth-the-best-solution-to-sasfiscal-challenges-19390636 Date of access: 16/09/2019. 